NBER WORKING PAPER SERIES

\title{
A NEW WORLD ORDER: EXPLAINING THE EMERGENCE OF THE CLASSICAL GOLD STANDARD
}

\author{
Christopher M. Meissner \\ Working Paper 9233 \\ http://www.nber.org/papers/w9233
NATIONAL BUREAU OF ECONOMIC RESEARCH
1050 Massachusetts Avenue
Cambridge, MA 02138
October 2002

I thank Barry Eichengreen, Brad DeLong, Christina Romer and Andy Rose for helpful comments. The comments of three anonymous referees and Jan de Vries were also beneficial. Seminar participants at the University of California at Berkeley and Rutgers also provided useful initial criticism. I bear responsibility for all remaining errors. I also acknowledge the I.B.E.R. at U.C. Berkeley for funding to collect a part of the data. The John L. Simpson Memorial fellowship from the Institute of International Studies at U.C. Berkeley also provided generous financial support. The views expressed herein are those of the author and not necessarily those of the National Bureau of Economic Research.

(C) 2002 by Christopher M. Meissner. All rights reserved. Short sections of text, not to exceed two paragraphs, may be quoted without explicit permission provided that full credit, including $(\subset$ notice, is given to the source. 
A New World Order: Explaining the Emergence of the Classical Gold Standard

Christopher M. Meissner

NBER Working Paper No. 9233

October 2002

JEL No. N10, F33

\title{
$\underline{\text { ABSTRACT }}$
}

The classical gold standard only gradually became an international monetary regime after 1870. This paper provides a cross-country analysis of why countries adopted when they did. I use duration analysis to show that network externalities operating through trade channels help explain the pattern of diffusion of the gold standard. Countries adopted the gold standard sooner when they had a large share of trade with other gold countries relative to GDP. The quality of the financial system also played a role. Support is found for the idea that a weak gold backing for paper currency emissions, possibly because of an unsustainable fiscal position or an un-sound banking system, delayed adoption. A large public debt burden also led to a later transition. Data are also consistent with the idea that nations adopted the gold standard earlier to lower the costs of borrowing on international capital markets. I find no evidence that the level of exchange rate volatility or agricultural interests mattered for the timing of adoption.

\author{
Christopher M. Meissner \\ Faculty of Economics and Politics \\ University of Cambridge \\ Austin Robinson Building \\ Sidgwick Avenue \\ Cambridge CB3 9DD ENGLAND \\ and NBER \\ chris.meissner@econ.cam.ac.uk
}




\section{Introduction}

In the waning decades of the nineteenth century, the world economy came to have a new global monetary system often referred to as the classical gold standard. In 1870 only Great Britain, Australia, Canada and Portugal had a gold standard. Shortly thereafter, matters began to change. By 1910, most nations had come to adopt a gold-based system.

This paper investigates this nearly universal adoption. In particular I ask why some countries adopted the gold standard earlier than others. Because the diffusion was gradual the years between 1870 and 1913 provide evidence on the cross-sectional and time series determinants of why countries prefer one monetary regime to another and why the international monetary system evolved as it did.

By joining the gold standard, countries pledged to trade a fixed quantity of gold for a certain amount of domestic currency units. Consequently, the classical gold standard generated a nearly global regime of fixed exchange rates and monetary uniformity reducing the transaction costs of trade between all gold standard countries. Hence, the rise of this system may have substantially affected global integration in the nineteenth century. ${ }^{1}$

This notion is consistent with recent research on exchange rate regimes. Rose (2000) shows that countries today in a currency union trade many times more than with those not in the particular union. ${ }^{2}$ More salient evidence comes from a global study by LópezCórdova and Meissner (2000) that reports the gold standard was associated with increases in bilateral trade of at least 30 percent between 1870 and $1910 .{ }^{3}$ In other words, coordination on a monetary regime may have a surprisingly large impact on economic

\footnotetext{
${ }^{1}$ Obstfeld and Rogoff (2000) show how small costs to trade can significantly increase the home-bias in consumption.

${ }^{2}$ Many studies have criticized Rose's results. It would appear that the magnitude of the effect depends on which country one studies (as in Persson (2001)) and that more data may be necessary to provide an adequate test (e.g., as in Nitsch (2002) and Tenreyro (2002)). Nevertheless Rose has either published or posted on his website (http://www.haas.berkeley.edu/ arose/RecRes.html) criticisms of most of these studies.

${ }^{3}$ López-Córdova and Meissner (2000) also find that membership in a monetary union in the late nineteenth century was associated with higher levels of trade. Similarly, Flandreau and Maurel (2001) report that monetary unions and the gold standard were associated with greater integration in Europe during the late 1800s.
} 
outcomes.

Geographic and historically specific events play a large role in explaining the timing of some of the crucial initial moves to a gold standard. Nevertheless, these shocks to the relatively stable older pattern of regime adherence gave rise to a path of adoption depending heavily on a few observable country-level characteristics which determined the benefits and costs of immediate versus delayed adoption.

To explore why some countries adopted the gold standard more rapidly than others after 1870, the paper discusses various explanations of monetary regime choice. The paper then tests these predictions econometrically using duration analysis. ${ }^{4}$ I find substantial evidence that network externalities matter for explaining the timing of the adoption of the gold standard. Joining the gold standard decreased the cost of trade with other gold standard countries. Consequently, countries adopted gold sooner the more they traded with other gold standard countries. Conversely, for bimetallic or silver countries, heavy trade links with others using the same standard may have led to a later adoption of the gold standard.

Some evidence also shows that nations needed institutional capability to join the gold club quickly. Nations with large note issues relative to gold reserves delayed adoption of the gold standard. This was typically coincident with weak public finances, but poor banking regulation was also to blame in some cases. Additional evidence shows that the level of output per capita accelerated the move to the gold standard.

Similarly the data are consistent with the idea that nations tried to reduce borrowing costs on global capital markets through institutional change. Bordo and Rockoff (1996) have found international evidence that gold standard adherence was connected with lower borrowing costs in the late nineteenth century. Logically, countries with higher borrowing costs for a given amount of borrowing would have an incentive to quickly adopt the gold standard.

\footnotetext{
${ }^{4}$ Though this is the first cross-country econometric study of the issue to my knowledge, many of the hypotheses I test have been put forward in the modern literature on the gold standard. See for example Eichengreen and Flandreau (1998), Flandreau (1996) and Gallarotti (1995).
} 
Statistical tests reject the idea that a number of other factors explain the timing of the move to gold convertibility. Econometric results show the gold standard was not implemented in the hope it would provide a defense against the level of nominal exchange rate volatility nor did agricultural interests resist a gold-based currency. Countries with large silver reserves did not delay adoption. These issues may have entered the political debates of the time or might have mattered in individual cases, but the cross-country analysis suggests they played no universal role in the decision of when to join.

I begin the study by briefly outlining the history of institutional reforms in the international monetary system between 1860 and 1913. In Section 3, I sketch a framework that neatly captures the issues nations faced when choosing when to adopt the gold standard. In the following section, I present the logic of a number of other hypotheses. In Section 5, I describe my econometric approach and present tests of the various hypotheses.

\section{A Brief History of the International Monetary Sys- tem, 1850 to 1913}

In the nineteenth century countries had a range of monetary systems available to them. Bimetallism, silver, gold and inconvertible fiat currencies were the prevalent monetary regimes. But prior to 1870 , few countries operated currencies exclusively convertible into gold. The important exception was Great Britain which established de jure gold monometallism in 1816 and returned to de facto gold convertibility in $1821 .^{5}$

During the 1850s, a number of bimetallic European states demonetized gold (Einaudi, (2001), p.23). Gold discoveries were shifting the market ratio of gold and silver, and Gresham's Law threatened inflation by eliminating concurrent circulation of both metals. ${ }^{6}$

\footnotetext{
${ }^{5}$ Australia, Canada and Portugal, adopted the gold standard in the early 1850s. Portugal had extensive commerce with England and a powerful debtor class that preferred an inflationary standard which gold was deemed to be in the 1850s (Reis (1998)).

${ }^{6}$ Russell (1898) claims that some bimetallic nations were overcome by this gold wave, and he attributed the 1860s discussion of moving to the gold standard as a desire to formalize this outcome. Similarly Redish (2000) argues that bimetallic countries were de facto gold countries in the 1860s. Flandreau (1996), however, argues that bimetallism in France experienced concurrent circulation of gold and silver throughout the period.
} 
But until 1872, when Germany embarked on national monetary reform and changed its standard from silver to gold, few countries explicitly made their currencies convertible exclusively into gold.

After 1870 only the rare country moved to adopt a regime other than gold or a fiat currency. ${ }^{7}$ Paper currencies often plagued nations that had been rocked by financial crises or had governments with extensive fiscal needs because of wars or weak governance. Nevertheless most paper countries aspired to return to convertibility. ${ }^{8}$ For example, Russia, Austria-Hungary and Spain were silver or bimetallic countries in 1870, but moved onto a fiat regime soon after 1870 due to wars and fiscal demands. Other countries like Italy had a fiat regime beginning in 1870 . After 1870, a return to convertibility meant adopting the gold standard for all of these countries.

The seeds of this shift were sown during the 1860s. At the International Monetary Conference of 1867 in Paris delegates representing 20 nations from Europe along with the United States, discussed the possibility of an international monetary union and the possibility of the worldwide adoption of a monometallic (i.e., either gold or silver) globally uniform system of coinage. The record shows most delegates supported a worldwide monetary union based on gold..$^{9}$

Einaudi (2000) discusses why a gold system was favored in 1867. Gold's dominance on the continent was partially attributable to forceful arguments by Parieu, vice-president of the French Council of State. Parieu cited gold's increasing use in Europe in the 1860s as an international currency and argued it was a regime that would strengthen ties with Britain and Germany (Einaudi, (2001), pp. 50-52). Other contributing factors included the alleged instability and inflationary bias of bimetallism, and an ideology holding that gold was the monetary regime of economically advanced nations.

\footnotetext{
${ }^{7}$ Indeed, of all economically important nations, only Japan comes to mind as a country that re-instated a silver standard in the 1880 s after having a paper currency.

${ }^{8}$ Nearly all commentators of the time viewed inflation and price fluctuations to be the hallmark of a fiat regime while metallic convertibility provided price stability. Just as the US had the Greenback Party, countries like Chile and Brazil had advocates of fiat regimes. Subercaseaux (1922) refers to the "papeleros" of Chile whereas Fritsch and Franco (2000) refer to the "papelistas" of Brazil. These groups opposed convertible currencies and alleged that they restricted commerce.

${ }^{9}$ See Russell (1898) for an early authoritative study of the conference.
} 
In terms of international coordination, the British position was important. Britain remained an observer rather than a participant at the Paris conference, and stubbornly plumped for keeping its own non-decimal gold-based system. This affinity for gold can only partially be explained. Einaudi (2000) describes how British policy makers feared the alleged instability of bimetallism. And gold itself was widely believed to be superior to silver both for historical and more economic reasons. In the years prior to 1816, Lord Liverpool helped to convince the British government that gold was the proper way of running monetary affairs merely because Britain had been effectively on gold for almost a century already (Seyd (1868)). Additionally, many believed that gold coinage was the most convenient for more developed countries which had large average values of transactions. Silver weighed more per unit of currency and hence implied greater carrying costs compared to gold. Redish (2000) includes a prominent role for the newfound minting technology which enabled production of non-counterfeitable token silver coins.

Furthermore, by the 1860s, Britain may have viewed the transition costs of a regime switch as avoidable. Its commercial and financial importance allowed policy makers to strategically attempt to guide other nations toward a gold-based system during the conference. In this way the nation would not have to incur re-coinage costs associated with moving to another system but could still reap the benefits of harmonization. But there was also doubt about the benefit of linking up to a non-gold European system since Britain already had extensive connection with its gold-based empire (Einaudi, 2000). The English representative to the conference argued for both of these opinions and declared, "Indeed, the English nation is in a position much more independent upon this question than most continental nations" (Russell, 1898 pp., 73-74).

In the end, the conference voted overwhelmingly for gold. Over the course of the next two decades, nations put action to words. Table 1 lists the dates of adoption of gold convertibility for a number of countries. ${ }^{10}$

\footnotetext{
${ }^{10}$ In the literature, there are discrepancies regarding the exact dates of adoption of the gold standard due to differences in definition. Some notable cases include Austria-Hungary, Argentina, and Norway. I
} 
Table 1: Year in which Countries Adopted the Gold Standard

\begin{tabular}{lrlr}
\hline \hline Country & $\begin{array}{c}\text { Year of adoption } \\
\text { of gold convertibility }\end{array}$ & Country (cont.) & $\begin{array}{c}\text { Year of adoption } \\
\text { of gold convertibility (cont.) }\end{array}$ \\
\hline Australia & 1852 & India & 1899 \\
Canada & 1853 & Costa Rica & 1900 \\
Portugal & 1854 & Ecuador & 1900 \\
Argentina & $1863,1883,1903$ & Philippines & 1903 \\
Uruguay & 1863 & Straits Settlements & 1903 \\
Colombia & 1871 & Siam & 1903 \\
Germany & 1872 & Mexico & 1905 \\
Sweden & 1873 & Brazil & 1906 \\
Denmark & 1873 & Bolivia & 1908 \\
Norway & 1873 & Greece & 1910 \\
Netherlands & 1875 & Nicaragua & 1912 \\
Finland & 1877 & Austria-Hungary & -- \\
Belgium & 1878 & Santo Domingo & -- \\
France & 1878 & Haiti & -- \\
Switzerland & 1878 & Bulgaria & --- \\
United States & 1879 & China & -- \\
Turkey & 1880 & Guatemala & -- \\
Italy & 1884 & Honduras & -- \\
Egypt & 1885 & Indonesia & -- \\
Chile & 1895 & Paraguay & -- \\
Romania & 1890 & Persia & -- \\
Salvador & 1892 & Peru & -- \\
Japan & 1897 & Spain & -- \\
Russia & 1897 & Venezuela & -- \\
\hline & & &
\end{tabular}

Note: This table uses the date of adoption of the free convertibility of a currency exclusively into gold. The entry "---" means that the country did not adopt gold convertibility before 1913.

\subsection{Making the Transition}

To join the gold standard, a country established and adhered to a law fixing a price between the domestic currency and a quantity of gold (and no other metals) and mandating the free coinage of gold and convertibility into gold. ${ }^{11}$ Additionally, national authorities may have declared a ratio of gold reserves and/or gold-convertible assets to outstanding liabilities which had to be maintained by note-issuing institutions. To obtain these reserves, most countries either sold silver reserves or borrowed the necessary funds on international capital markets. Whether a country enacted a bullion standard as in Holland or a gold exchange standard as in India or the Philippines, the net effect on transaction costs was the same. Exchange rates were stabilized, homogenization was established and any note or bill denominated in the local currency could ultimately be exchanged exclusively for gold.

use the dates at which a national currency became de facto and de jure convertible into gold by law and only the free coinage of gold was allowed. A list of sources used is in the data appendix.

${ }^{11}$ Of course some nations also had a token silver coinage. 
For more developed countries in Europe, the early transition to gold meant simply redefining the national currency strictly in terms of gold and purchasing adequate gold reserves. For already convertible currencies, the particular amount of gold chosen per currency unit usually resulted in the amount that maintained the historical level of the nominal exchange rate vis-à-vis a gold currency like England.

Paper countries faced a different scenario. It took nearly 14 years for the inconvertible American Greenback dollar to recover the antebellum nominal exchange rate against sterling. On the other hand, Russia in 1897 and Argentina in 1899 took a shortcut by adjusting their par values downward and resuming convertibility with a nominally depreciated currency. Finally, less developed countries often packaged the initiation of the gold standard with the creation of a national currency system. Countries like Argentina in 1884 and the Philippines in 1903 radically revamped their historically chaotic monetary systems instituting a gold standard at the same time (Cuccorese (1972) and U.S. Commission on International Exchange (1904)).

\subsection{The Dominoes Fall}

In 1872 Germany initiated the worldwide shift by abandoning silver for gold. Germany's new regime can largely be explained as the actualization of preferences manifested in Paris in 1867 which in turn reflected its commercial connections. However, the precise timing of the adoption appears to have coincided with victory in the Franco-Prussian war (which made acquisition of gold less costly), national unification and the creation of a national monetary system. Germany's reform demolished the viability of the historical monetary equilibrium. It set off a domino effect.

Norway, Sweden and Denmark followed suit and adopted the gold standard in $1873 .{ }^{12}$ In the meantime, France limited silver coinage in late 1873. As Flandreau (1996) illustrates this was an attempt to hinder German silver sales which could have massively devalued its silver reserves. France, accompanied by Belgium and Switzerland, chose the

\footnotetext{
${ }^{12}$ See Talia (2001).
} 
gold standard definitively in 1878 . The United States regained gold convertibility of the dollar in 1879.

Nations in the less-developed periphery, with histories of paper currency regimes, fiscal difficulties and less connection to international commerce, waited until after the 1870s to adopt. Italy made the leap in 1884. Spain rescinded bimetallism in 1883 but never adopted gold. Greece tried adopting the gold standard in 1885, but was pushed off in the same year due to a financial crisis (Dritsas (1999)); eventually it adopted gold in 1910. Austria-Hungary never adopted de jure gold convertibility, but it managed to stabilize its currency circa 1896 through discretionary convertibility (see Flandreau and Komlos (2002)). In the late 1890s and early 1900s, gold regimes diffused to many parts of Latin America and Asia. Ultimately, on the eve of World War I, most of the world had managed to adopt the gold standard.

\section{Benefits and Costs}

In this section, I discuss the trade-offs a nation faced when joining the gold standard. In part, nations chose the gold standard to economize on the costs of trade. The larger the gold bloc was the greater the cost savings; as Flandreau (1996) argued in the case of Western Europe, monetary regimes exhibited network externalities or strategic complementarities and bimetallism or silver might have served equally well as gold. There was no inexorable move towards the most efficient system. At the global level, historical events interacting with economic fundamentals determined the path of diffusion and the ultimate outcome. Nevertheless there are other hypotheses that might partially explain the pattern of adoption of the gold standard. 


\subsection{Decreasing Transaction Costs and Network Externalities}

A shared commodity money regime decreased some of the transaction costs of trade. ${ }^{13}$ None of these costs were large in an economic sense, but under plausible scenarios they may have been non-negligible. ${ }^{14}$ Consistent with this contemporaries often cited these costs as important determinants in their decisions. ${ }^{15}$

One cost affecting international commerce was exchange rate movement. Instruments for hedging these slippages were rudimentary and costly. Unger (1964) explains how during the period of dollar inconvertibility following the Civil War an American exporter with sterling income and dollar liabilities hedged his exposure. ${ }^{16}$ The merchant would borrow one dollar of gold after completing an order and immediately sell the gold at the spot rate for a paper dollar also known as a "greenback". If the greenback appreciated vis-à-vis gold, the exporter would earn fewer greenbacks for each pound sterling of merchandise ordered. However, the hedge ensured fewer greenbacks would be needed to re-pay the borrowed gold. The difference between the amount earned and the amount gained from the spot sale could in part recuperate the losses in the goods market. The transaction cost included the opportunity cost of the time and resources devoted to the transaction, other broker's fees and the interest charge.

One other transaction cost was the exchange of precious metals that occurred from time-to-time between countries on different standards (Meyer (1878)). These exchanges implied broker's fees that could be avoided if nations shared a common regime. This may have been one primary concern for nations in the 1860s because exchange rate

\footnotetext{
${ }^{13}$ Einaudi (2000) discusses why even a full monetary union in the nineteenth century could not eliminate the charges made to buy foreign instruments of payment. And because travellers rarely carried coins, precious metal exchange commissions could not be foregone either. However there are other important costs which could be eliminated by adopting a common commodity regime.

${ }^{14}$ See Obstfeld and Rogoff (2000).

${ }^{15}$ Gallarotti (1995) argues that countries preferred the commodity standards of the majority of their trading partners. Eichengreen (1996) writes that network externalities operated to make the gold standard an attractive monetary regime and Flandreau (1996) argues that such strategic complementarities affected regime choice and analyzes in depth the French and German choice. The specific transaction costs outlined below are consistent with this previous work.

${ }^{16}$ Slippage between income and expenses could rely on sticky nominal prices, or incomplete exchange rate pass-through on export sales.
} 
volatility was minimal between the gold, silver and bimetallic blocs prior to 1872 . French bimetallism pegged the gold price of silver rendering the need to hedge un-important (Flandreau (1996)).

Identifying these costs reminds us that silver and bimetallic standards conferred network externalities as well, and these could have emerged as the global standard. These alternative standards benefited from the same qualities as a gold standard as long as nations were coordinating. ${ }^{17}$ Early patterns of trade can largely explain the existence of three distinct regime blocs in Europe prior to the 1870s.

Moreover, motions for an international gold coinage surfaced in the 1860s, precisely when integration with the workshop of the world was increasing. The conference record shows that Scandinavian countries were strong advocates of gold as were the delegates from many German states. Both regions had strong and quickly growing trade links to gold countries (as represented by trade with Britain) as Figure 1 shows. In Germany trade with Britain was nearly more significant than trade with silver countries, and it was likely to have been expected to keep growing with continuing structural change. Holland, a major silver trading partner, could be expected to switch to gold after Germany as was declared in Paris in 1867.

Trade between Sweden and Britain greatly accelerated in the 1860s. In Norway silver dominated only if Sweden and Germany remained on the silver standard. At the other end of the spectrum, conference advocates of silver like Russia and Holland with strong connections to silver-based countries in Asia strongly opposed a monometallic gold standard. Nevertheless, Holland conceded it would admit a gold standard if its trading partners in Europe moved to gold (Russell, 1898).

Illustrative of these strategic complementarities is the case of Scandinavia. Denmark, Sweden and Norway, all silver countries prior to 1873, met at the Nordic economic meetings in 1872 and made a joint decision about monetary regime choice (Henriksen and

\footnotetext{
${ }^{17}$ The theoretical downside to bimetallism - uncertainty of the metallic circulation - has been shown to be empirically specious in France during the 1850s and 1860s by Flandreau. However, most at the Conference of 1867 viewed bimetallism as a non-viable regime because of this problem and an alleged inflationary tendency (see Einaudi, 2001).
} 
Figure 1: Trade Levels by Regime for Various Countries
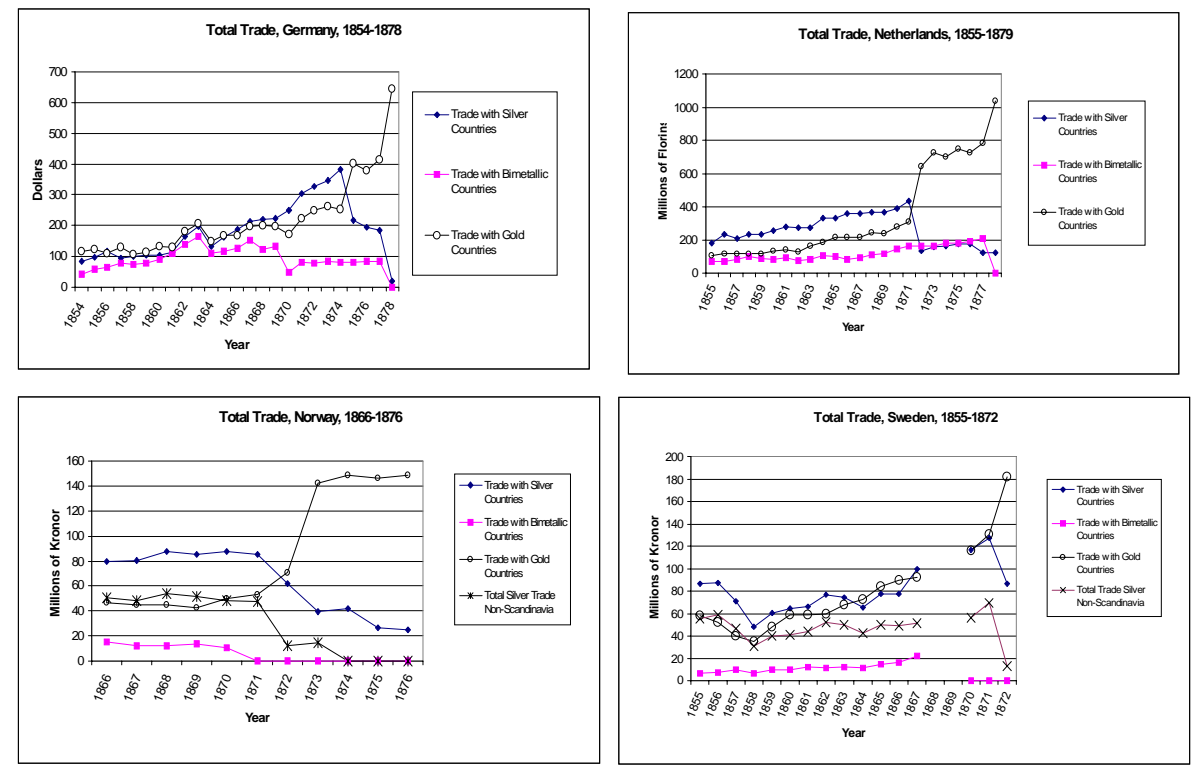

Note: Data are from Mitchell (1992) and are in nominal terms.

Kaergard (1995) and Talia (2001)). By making a multilateral decision with their principal trading partners, no country had to forego any of the benefits of coordination by making a unilateral deviation to gold - even if those losses might be temporary. When Germany adopted gold, and French-led bimetallism foundered, the choice was clearly gold.

Flandreau (1996) cites a French survey from 1868. This source tellingly reveals the origin of national preferences over monetary regimes. Merchants engaged in trade with England plumped for a gold standard. The east and south of France apparently preferred a silver regime because of the greater amount of trade with silver regions like the German states, Austria-Hungary, Russia and Asia. ${ }^{18}$

Importers from the U.S., testifying to the Silver Commission of 1876, declared their support for the gold standard. A.A. Low, an American importer of Chinese merchandise,

\footnotetext{
${ }^{18}$ Flandreau cites similar evidence in Germany. Also, Redish (2000) notes that the attempt to maintain de jure bimetallism in France was a bargaining chip in Monetary Union negotiations willing to be traded for other concessions. Einaudi (2001) sees opposition residing in conservative players like the Bank of France and the Parliament.
} 
advocated the gold standard because his purchases were made through London in sterling. For merchants like A.A. Low, sharing a common metallic standard with London saved broker's commissions (Meyer (1878) and United States Monetary Commission (1879)). Also, J.S. Moore, a U.S. Treasury official testified as follows:

Q. 118. Do you not think that the use of a common standard of value has a tendency to promote a free commercial interchange between the various countries using it?

A. . . . and if two countries, be they ever so distant from each other should have the same standard of money . . . there would be no greater harmonizer than such an exchange. If our silver dollar were to pass current in Mexico and South America, or if we had a union dollar, we should have much more of their trade and intercourse . . .(United States Monetary Commission (1879)).

In southern Europe and to some extent even in the US events moved slower perhaps because trade links were naturally weaker. Financial problems are also likely to blame and are discussed below. Still, as more and more countries joined the golden bandwagon, countries like Spain, Italy and Austria-Hungary had the trade incentives to join. Indeed, in Austria one commentator figuratively remarked in the 1890s that "he who would have dealings with others must speak their language" and that the decision for AustriaHungary had been made by the actions of western Europe (Willis (1899)).

Trade ties also came to be important in the non-European periphery. An American commission investigating China's possible adoption of the gold standard argued:

'The chief purpose of establishing a gold unit as a standard is to facilitate trade, and that largely with foreign countries . . . (moving to the gold standard) will tend to increase decidedly both the import and export trade of China. After Russia had established her system on a gold basis her foreign trade increased very 
decidedly, and a similar result was shown in Japan.' ((Commission on International Exchange 1904), p. 94 and p. 120).

A leading figure in Japan, Count Matsukata Masayoshi, suggested that one benefit of joining the gold standard would be in extending commerce with countries of the same standard [(Masayoshi 1899), p. 191]. Argentina's trade-oriented exterior regions also were long-time advocates of a gold-based system (Cuccorese (1972)). Debates in the Straits Settlements echoed the trade dimension of the choice too (Ding, 1978). Transaction costs surfaced as a major factor in the decisions of diverse countries.

Given the existence of these costs, nations would be more likely to adopt gold and hence would be expected to adopt earlier the more they traded with the gold bloc or as the gold bloc's importance in trade increased. Similarly nations would wait longer to adopt gold if they already belonged to the silver or bimetallic bloc and traded heavily with the other countries of that regime. Such nations, by adopting gold, would be foregoing the lower costs of trade they experienced with members of the status quo regime. ${ }^{19}$

\subsection{Institutional Capability}

While transaction costs were important they are probably not sufficient to explain the emergence of the international gold standard. Under the gold standard, spendthrift governments and/or poorly-designed, badly-regulated banking systems could thwart convertibility or bring on a costly financial crisis if convertibility was enacted. So, to adopt the gold standard early on, it appears sound government finances that allowed for a solid banking system were necessary. In fact, no fiat currency country in my sample adopted gold before 1878. The median date of adoption for paper countries in my sample is 1896 .

\footnotetext{
${ }^{19} \mathrm{I}$ am implicitly arguing that nations would find gold more valuable the greater the symmetry of relative price shocks and output shocks to the rest of the gold bloc. Essentially I follow Alesina and Barro (2000) and assume that symmetry is greater the more integrated a nation is with a country on the gold standard. For example Holland went onto silver in 1847 after having been on the gold standard. It declared that being on gold was difficult when in close proximity to Great Britain. Each financial crisis in Britain initiated an unsupportable drain of gold from Holland (United States Monetary Commission $(1879))$.
} 
On the other hand, for countries in the sample which were already convertible in 1870 , the median date of adoption was 1875 .

Paper currencies were typically a hangover from or a necessary component to heavy fiscal demands from central governments. These could stifle the switch to gold convertibility when reserves could not keep pace with the printing presses or when speculation drained a country's gold. A country desiring to make the transition might also have to manufacture a politically difficult reform to eliminate fiscal excess or at least protractedly discuss the best route to convertibility. Perhaps a legal framework limiting over-extensions or political involvement in the banking sector would need to be drawn up. Political mechanisms preventing the monetization of debt or the entrenchment of spendthrift interest groups might have been necessary (see for instance Rousseau and Sylla (2001) on Japan or Bordo and Végh (1998) on Argentina).

The postbellum American experience points out how difficult it was for paper countries to negotiate resumption of convertibility (Unger (1964) and United States Monetary Commission (1879)). A large portion of the U.S. Silver Commission's hearings were devoted to gleaning opinions on the best method of financing the retirement of outstanding U.S. government greenbacks. Political debates over resumption lasted many years after the war, and sharp polarization on the currency issue led to fits and starts in financial policy.

In the 1880s Brazil and Argentina both had weakly regulated banking systems combined with financially strapped governments meddling in the business of leading banks. ${ }^{20}$ These countries succumbed to over-expansion culminating in the Baring's Crisis and the crack of the "encilhamento". Financial austerity, banking reform and debt re-scheduling during the 1890s allowed both countries to obtain the solid foundations necessary to credibly maintain convertibility by the first decade of the twentieth century. In Italy during the 1870s and late 1880s private bank credit expanded rapidly contributing to hoarding and export of gold in turn generating currency depreciation (Tattara, (2000)).

\footnotetext{
${ }^{20}$ On Brazil see Fritsch and Franco (2000) and on Argentina see Eichengreen (1999)
} 
Other peripheral countries like Austria-Hungary, Greece, Russia and Spain also had fiscal deficiencies throughout the 1870 s and 1880s. ${ }^{21}$ Persistent government deficits leading to large debts may have made moving to gold convertibility more arduous. The public might not trust the convertibility pledge and gold reserves could be difficult to find and maintain. In Italy during the 1870 s the low credibility and hence low prices of government bonds made borrowing to obtain gold more difficult (Tattara (2000)). Japan finally adopted gold in 1897 after Count Matsukata's long struggle to put the country's finances on track (see Rousseau and Sylla (2001)).

Countries with weak banking sectors or fiscally over-stretched governments would have to effect institutional innovation before they could join the gold standard. Those able to maintain strong gold reserve ratios and which enjoyed fiscally responsible governments may have made the transition to gold much faster than other countries.

\subsection{Other Hypotheses}

A number of other hypotheses that might explain the pattern of adoption of gold regimes have been developed in the literature. I discuss each in turn along with their implications for the timing of the adoption of the gold standard after 1870 .

\section{The "Good Housekeeping Seal of Approval"}

Work by Bordo and Rockoff (1996) suggests that adopting the gold standard lowered the cost of borrowing on international capital markets. By credibly adopting convertibility, nations promised to maintain stable exchange rates, not to follow a policy of gradual inflation and to return to the par value of exchange after a large shock forced inconvertibility (Bordo and Kydland (1997)). Stability of exchange rates in the long and short-term was virtually guaranteed. This provided insurance that liabilities would not be inflated away and exchange rate risk for lenders was minimized.

\footnotetext{
${ }^{21}$ Many of the costs and difficulties that the move to gold implied for paper regimes have been extensively discussed in the national histories. For the countries in my econometric sample, see Flandreau, Le-Cacheux, and Zumer (1998) or Flandreau and Komlos (2002) on Austria-Hungary, Lazaretou (1995) on Greece, García-Iglesias Soto (1998) and Aceña (2000) on Spain, Fritsch and Franco (2000), pp. 154157, on Brazil and Barkai (1973) or Crisp (1953) on Russia. See also Llona-Rodríguez (2000) on Chile and Reis (2000) on Portugal.
} 
Flandreau (2000) argues that nations increased financial linkages with Paris in the nineteenth century by joining the Latin Monetary Union. This increased the "legibility" of foreign liabilities for French creditors. It may be that the gold standard also sent a similar signal to creditors.

Anecdotally, many nations cited cheaper capital market access as a consideration in their adoption. Russian policy-makers were motivated by lowering the cost of borrowing on international capital markets. Crisp (1953) argues that the adoption of the gold standard brought forward large amounts of financing and lowered borrowing costs in Paris. The American Commission on International Exchange (1904) remarked that capital would flow to China if the gold standard were adopted. Japan adopted gold to obtain less expensive funds on the London markets, and Masayoshi (1899) cited this as one of the motivations for establishing a gold standard (see also Sussman and Yafeh (2000)). Countries with high borrowing costs would have deep incentives to quickly attain the gold standard seal of approval.

\section{Level of Development}

Higher output per capita may also have led to earlier adoption of gold convertibility. Redish (1990) argues that developed countries with transactions of greater value than less developed countries could save on carrying costs by transacting in a gram-for-gram more valuable metal like gold. Eichengreen and Flandreau (1998) and Bordo and Flandreau (2001) note higher per capita incomes coincided with a number of favorable conditions including the existence of a strong financial system and access to gold reserves. ${ }^{22}$

\section{Gold Reserves}

Aside from being a proxy measure of banking ability or fiscal restraint, gold reserves may also simply be a necessary factor in moving to the gold standard. Eichengreen and Flandreau (1998) emphasize that nations required an adequate amount of gold relative to domestic liabilities in order to make a quick transition to the gold standard. ${ }^{23}$

\footnotetext{
${ }^{22}$ Rousseau and Sylla (2001) present evidence that sound finances lead to higher growth.

${ }^{23}$ Of course this assumes that nations do not decrease the value of their currencies in terms of gold too radically. This seems to be the case historically. The only significant countries that altered the par value of currency were Argentina, Austria-Hungary (which never fully went back to convertibility), Chile and
} 


\section{Silver Reserves}

Gallarotti (1995) and Eichengreen and Flandreau (1998), along with many contemporaries, thought that it would take longer to switch to gold if a country had large amounts of silver reserves. Quickly exchanging silver reserves for gold on world markets had the potential to depress the price of silver bringing losses on such asset sales. Observers argued that Scandinavia and Holland were able to switch rapidly to gold because of their relatively small silver holdings. France, with elephantine silver reserves, had to reflect more carefully on the impact of such a regime change.

\section{Debtors versus Creditors}

It is often claimed that regime choice was a political power struggle between an urban, creditor class and a rural, debtor class (de Cecco (1974)). The gold standard allegedly represented deflation and increasing real values of nominal debt contracts. In testimonies from the U.S. Monetary Commission, many argued that re-instating a silver standard would benefit rural debtors. The prediction is that nations with a large proportion of rural interests in the economy would wait longer to adopt the gold standard.

\section{The Search for Stability}

Some of the current theoretical literature on exchange rates argues that merchants eschew exchange rate volatility. Exchange rate volatility increases risk and uncertainty and may increase the cost of carrying out a foreign transaction. ${ }^{24}$ By adopting the gold standard, nations could limit volatility against a group of important commercial nations already on gold. In the 1900s, volatility appears to have been of paramount concern for the silver-using nations of southeast Asia (U.S. Commission on International Exchange (1904)). All else equal, nations should have adopted the gold standard early on when they experienced high exchange rate volatility.

\section{The Ideology of Gold}

Political actors may also have identified the gold standard as the monetary institution Russia.

${ }^{24}$ Many empirical studies in the twentieth century have found that exchange rate volatility matters little for international trade flows. See Moreno (2000), Obstfeld (1997) and Wyplosz (1997) for summaries. 
of advanced nations (e.g., Gallarotti, 1995). In other words, a gold standard ideology may have infected the planet in the late nineteenth century. This would imply that there were bandwagon effects unrelated to economic factors. If so the propensity of a country to move to gold should simply be an increasing function of the total number of countries on gold or at least the population-weighted number of nations on gold.

Many ideas have been put forward as to why countries adopted the gold standard when they did. Some relate adoption to open-economy factors like cost savings in trade, the level or the variability of the exchange rate or the incentive to save on the costs of external borrowing. Others focus on domestic structural issues such as the degree of financial responsibility, the level of development, the struggle between creditors and debtors or the composition and quantity of reserves. I now present empirical tests of these competing hypotheses.

\section{Data and Sources}

The data set I use to test these hypotheses is an unbalanced panel of macroeconomic variables for 19 countries from 1870 to 1913. I compiled the data from a number of historical and contemporary sources. ${ }^{25}$ Table 2 presents summary statistics for each of my explanatory variables.

The median date of adoption in my sample is 1879. The earliest date of adoption for which I have complete data is 1872, and the latest is 1910. I have three censored observations in the sample - Spain, Austria-Hungary and Italy - which were not on gold when my sample ends. Observations in a given year are not used when there is a missing value for one of the covariates.

To test the first part of the monetary homogenization hypothesis (i.e., a common regime was likely to decrease the costs of trade), I used the ratio of the nominal value of exports and imports with all gold standard countries to nominal GDP as an explanatory

\footnotetext{
${ }^{25}$ The full data set and notes on country specific sources are available from the author upon request. The data appendix gives references for various series. Table 6 in the appendix presents availability of data for the countries and variables in my sample.
} 
Table 2: Summary Statistics of Variables

\begin{tabular}{|c|c|c|c|c|c|}
\hline 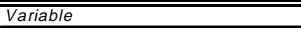 & Observations & Mean & Standard Deviation & Minimum & Maximum \\
\hline Years until adoption after 1870 & 19 & 9 (median) & -.. & 2 & 40 \\
\hline $\begin{array}{l}\text { Ratio of trade with gold } \\
\text { standard countries to GDP }\end{array}$ & 351 & 17.80 & 11.63 & 0.57 & 61.30 \\
\hline $\begin{array}{l}\text { Ratio of trade with countries on } \\
\text { same standard to GDP }\end{array}$ & 354 & 1.92 & 5.36 & 0.00 & 41.44 \\
\hline Paper Dummy & 402 & 0.75 & 0.44 & 0.00 & 1.00 \\
\hline $\begin{array}{l}\text { Ratio of gold reserves } \\
\text { to notes outstanding }\end{array}$ & 249 & 24.79 & 19.50 & 0.00 & 138.10 \\
\hline $\begin{array}{l}\text { Silver Reserves } \\
\text { (millions of pounds sterling) }\end{array}$ & 220 & 6.25 & 6.75 & 0.00 & 42.05 \\
\hline In (real per capita GDP) & 204 & 7.23 & 0.58 & 6.03 & 8.24 \\
\hline deficit/GDP & 313 & 1.89 & 3.94 & -6.87 & 34.40 \\
\hline debt/GDP & 165 & 44.91 & 42.12 & 0.65 & 144.60 \\
\hline Spread on Government bonds & 343 & 4.26 & 5.76 & 0.18 & 49.39 \\
\hline Ratio of Agricultural output to GDP & 327 & 46.26 & 14.01 & 19.00 & 78.28 \\
\hline $\begin{array}{l}\text { Weighted exchange rate volatility } \\
\text { vis-à-vis gold standard countries }\end{array}$ & 394 & 1.22 & 1.58 & 0.00 & 7.25 \\
\hline In (population) & 402 & 2.39 & 1.28 & 0.03 & 4.84 \\
\hline $\begin{array}{l}\text { Average distance from the country } \\
\text { to gold standard countries at time } t\end{array}$ & 402 & 8.00 & 0.63 & 6.85 & 8.96 \\
\hline $\begin{array}{l}\text { Border dummy (one if at least } \\
\text { one gold country on border) }\end{array}$ & 402 & 0.68 & 0.47 & 0.00 & 1.00 \\
\hline
\end{tabular}

Note: For the sources and countries included see the data appendix.

variable. I also control for the benefits to the status quo commodity money regime. For silver and bimetallic countries, I use the ratio of the level of trade to GDP with countries on a similar commodity money standard. Paper countries receive a zero for this variable.

I control for the "good housekeeping" effect with the difference between the domestic long-term government bond yield and the British consol rate. I control for government finances with the level of the annual deficit scaled by GDP or alternatively the level of debt outstanding to GDP. Another measure of government finances or the strength of the banking sector is included with the ratio of gold reserves to notes in circulation.

Yet another alternative measure of fiscal prudence is an indicator variable equal to one if a country had a fiat money regime in a given year and zero otherwise. A zero is a rough proxy for good public financial responsibility. Nevertheless, this indicator variable could pick up the effect of any or all of the following characteristics: prudent expansion and/or regulation of the banking system; restrained fiscal demands; long-run credibility; organized cooperation among financial institutions to avoid systemic liquidity problems 
in times of panic; and finally the avoidance of costly wars. I justify using an indicator variable here because some of these traits are hard to operationalize and it is difficult to control separately for each in my small sample.

I measure the level of development by using the natural logarithm of real output per capita. The figures are in 1990 PPP-adjusted U.S. dollars. I also use information on the absolute size of silver reserves which I convert to pounds sterling at the current annual average exchange rate. This tests the notion that large silver reserves impeded adoption of the gold standard. Rural, debtor interests in the economy are measured with the ratio of agricultural output to total GDP. Finally, I use a measure of weighted exchange rate volatility to control for losses associated with instability. ${ }^{26}$ To test the ideology hypothesis I use the total number of countries adhering to gold. ${ }^{27}$

\section{Empirical Approach and Results}

In this section, I outline the duration analysis approach. I then discuss the estimated relationships between the explanatory variables and the time until adoption after 1870 . The next sub-section tests the robustness of the results for a variety of potential problems.

\subsection{Duration Analysis}

Duration models estimate the association between explanatory variables and the time conditional probability (i.e., the hazard rate) of making a transition from one state to another. ${ }^{28}$ The dependent variable is coded as a one if a country moved to the gold standard in a given year having been a silver, bimetallic or paper country in the previous year and zero if it had one of those regimes but did not move to gold in a given year.

\footnotetext{
${ }^{26}$ The raw measure of bilateral exchange rate volatility is the standard deviation of the difference $\ln \left(e_{i j t}\right)-\ln \left(e_{i j t-1}\right)$ (where $e_{i j t}$ is the bilateral exchange rate between country $i$ and $j$ at month $t$ ) for the previous three years. For the weighting scheme, I used a three-year moving-average of the weight of trading partners on the gold standard in total trade.

${ }^{27} \mathrm{I}$ also used a population weighted percentage of countries on gold. This measure was statistically un-related to the dependent variable in a number of specifications.

${ }^{28}$ The hazard rate is roughly the probability of transitioning from one state to another given that no transition has previously been made. If $T$ is a non-negative random variable denoting the time of an event, then the time-specific probability (hazard) of an event is defined as $h(t)=\lim _{\Delta \rightarrow 0^{+}} \frac{\operatorname{pr}(t \leq T<t+\Delta \mid t \leq T)}{\Delta}$
} 
Explanatory variables take on their current values in each year of observation. Countries leave the sample if they are on a gold standard, but can re-enter the sample if at any time they go off the gold standard.

Duration models use cross-sectional and time-series variation in the explanatory variables to identify the relationship between covariates and the event of interest. One benefit of duration models is that they conserve valuable information about the timing of events and can incorporate time related dependence affecting the hazard rate. Censoring is easily handled for observations not adopting gold by 1913. I have chosen 1870 as an initial date. Since virtually no significant country on the planet adopted the gold standard during the 1860s when regime change became imminent, there is no censoring problem associated with beginning observations in 1870 .

One example of a hazard model is the Weibull parameterization of the hazard rate. ${ }^{29}$ Its hazard rate can be written

$$
h(t)=p t^{p-1}\left[\exp \left(x(t)^{\prime} \beta\right)\right]
$$

where $p$ and $\beta$ are a parameters to be estimated. If $p>1$ the hazard rate increases over time. If $p<1$ the hazard decreases over time, and if $p=1$ the hazard rate is constant over time. The latter case is an exponential parameterization. Also, $x(t)$ is a vector of time-varying covariates.; $\beta$ is a vector of parameters describing the magnitude of the association between covariates and the hazard rate; $t$ is the time at observation.

The results below restrict $p=1$, and assume an exponential model of the hazard rate. $^{30}$ This assumes that the number of years a country waited to join the gold standard had no impact on the hazard rate of adoption of the gold standard.

The duration model above can be estimated by maximum likelihood. The log-

\footnotetext{
${ }^{29}$ To justify this, an earlier version of this paper reported the non-parametric estimator of the hazard rate for the full sample of countries reported in Table 1. That figure shows the hazard rate of switching to gold convertibility may have increased slightly over time or was flat. This suggests the use of a parametric model which allows an increasing or a constant hazard rate.

${ }^{30}$ Imposing this restriction does not alter the results, and the validity of this restriction was checked by means of a likelihood ratio test. Throughout the empirical section, I use robust standard errors of the estimators to take into account the dependence among country-observations in the sample.
} 
likelihood function consists of two parts - the contribution to the probability of an adoption by those that adopt in any year $t$ and the contribution to the likelihood of all those who adopt gold after or are censored in year $t$. I maximize the log-likelihood function

$$
l=\sum_{t=0}^{43} \sum_{i=1}^{N} \delta_{i} \ln h\left(x_{i}(t), \beta\right)-\sum_{t=0}^{43} \sum_{i=1}^{N} \ln \left[S\left(t, x_{i}(t), \beta\right)\right]
$$

where $i$ is an index of the $N$ countries in the sample between 1870 and 1913 (each country drops out of the sample in subsequent years if it moves to gold at time $t$ ), $\delta$ is an indicator equal to one if country $i$ adopted the gold standard at time $t$ and zero if it was censored in a given year (i.e., did not adopt the gold standard), $t$ is the time in years after 1870, $S$ is the survivor function (i.e., the probability that adoption of gold happens at time $t$ or later) and $h$ is the hazard function of the random variable "adoption of the gold standard at time $T^{\prime \prime}$.

Since this paper is interested in explaining the timing of adoption after 1870 it is more interesting to focus on the convenient and intuitive timing interpretation of hazard models. This model is called the accelerated failure time (AFT) model and can be derived from most hazard parameterizations. ${ }^{31}$ Such a model can be written as

$$
\ln t_{i}=x_{i}(t)^{\prime} \alpha+\varepsilon_{i}(t)
$$

where $x_{i}(t)$ is a vector of covariates for country $i$ in year $t, \alpha$ measures the relationship between the years until adoption of the gold standard and the covariates and is approximately equal to $-\beta$ and $\varepsilon_{i}(t)$ is a country-specific error term independent of $x_{i}(t)$.

\subsection{Baseline Results}

As a first approach I propose a parsimonious specification to explain the timing of the adoption of the gold standard after 1870. I initially only control for network effects operating through the trade channel, fitness of the financial system, the good housekeeping

\footnotetext{
${ }^{31}$ See Allison (1995) for a derivation.
} 
signalling mechanism and real GDP per capita. ${ }^{32}$ Results are reported in Table 3.

The coefficient on the ratio of trade with gold standard countries to GDP is significant at the one percent level. A one standard deviation increase in the ratio of trade with gold standard countries to GDP decreases the time until adoption after 1870 by nearly 92 $(\approx 12 \cdot 100(\exp (-.08)-1))$ percent. This drops the median expected time to adoption from 1879 to about 1871. The network effect operating through countries on the same status quo standard, which should delay adoption, has a positive sign, as would be predicted in a network effects model, but it is statistically insignificant. ${ }^{33}$

A stronger financial system proxied by a higher gold cover ratio is associated with earlier adoption times. However, one should be cautious because the level of gold reserves to notes outstanding may be endogenous to the desire or ability to go onto gold. The estimated coefficient may overstate the true association between a well-run banking system and adoption. The regressions are consistent with the idea that an over-expansion of liabilities in the banking system - whether because of government interference and fiscal problems or because of poor regulation - delays adoption. The anecdotal evidence above suggests that it is most often poor public finances rather than weak banking systems giving rise to this association.

The regressions also imply that a higher bond spread for a given level of deficit would lead to earlier adoption and vice-versa. These results are consistent with the idea that the gold standard served as a good housekeeping signal. If countries could lower the costs of borrowing by joining the gold standard, the incentive to join may have been greater for a larger spread and a given level of borrowing. ${ }^{34}$

\footnotetext{
${ }^{32}$ Below I include other covariates mentioned in Section 3.3. A log-likelihood ratio test suggests that a parsimonious model provides an adequate explanation.

${ }^{33} \mathrm{Un}$-reported regressions show that if France is coded as bimetallic from 1870 to 1878 this variable is associated with delayed adoption, and is almost statistically significant ( $\mathrm{p}$-value 0.15). Though France was de facto inconvertible until 1874 (Flandreau (2000)), the decisions of Belgium, Switzerland and France were partially taken by consensus because of affiliations with the Latin Monetary Union (Redish, 2000 pp.199-200).

${ }^{34} \mathrm{I}$ also included an interaction between the spread variable and the scaled deficit. The interaction term was statistically insignificant, but the point estimate was positive. This implies that high borrowing needs diminished the acceleration effect of a higher spread making it negative at deficit to GDP ratios of around five percent. Similarly including the square of the deficit term implies a later adoption for high
} 
Table 3: Baseline Regressions

\begin{tabular}{|c|c|c|c|}
\hline Explanatory Variable & Baseline & $\begin{array}{l}\text { Weak Government } \\
\text { Finances }\end{array}$ & $\begin{array}{c}\text { Paper } \\
\text { Regimes }\end{array}$ \\
\hline $\begin{array}{l}\text { Ratio of trade with } \\
\text { gold standard countries to GDP }\end{array}$ & $\begin{array}{l}-0.087 \\
(0.000)\end{array}$ & $\begin{array}{c}-0.19 \\
(0.000)\end{array}$ & $\begin{array}{l}-0.136 \\
(0.042)\end{array}$ \\
\hline $\begin{array}{l}\text { Ratio of trade with countries } \\
\text { on same standard to GDP }\end{array}$ & $\begin{array}{c}0.008 \\
(0.921)\end{array}$ & $\begin{array}{l}-0.039 \\
(0.662)\end{array}$ & $\begin{array}{l}-0.021 \\
(0.805)\end{array}$ \\
\hline In (real per capita output) & $\begin{array}{l}-2.414 \\
(0.017)\end{array}$ & $\begin{array}{c}0.322 \\
(0.800)\end{array}$ & $\begin{array}{l}-3.034 \\
(0.021)\end{array}$ \\
\hline $\begin{array}{l}\text { Ratio of gold reserves } \\
\text { to notes outstanding }\end{array}$ & $\begin{array}{l}-0.076 \\
(0.000)\end{array}$ & $\begin{array}{l}-0.161 \\
(0.000)\end{array}$ & $\begin{array}{l}-0.087 \\
(0.002)\end{array}$ \\
\hline Bond Spread & $\begin{array}{c}-0.781 \\
(0.092)\end{array}$ & $\begin{array}{l}-1.095 \\
(0.001)\end{array}$ & $\begin{array}{l}-0.97 \\
(0.088)\end{array}$ \\
\hline Ratio of deficit to output & $\begin{array}{l}-0.489 \\
(0.000)\end{array}$ & $\begin{array}{c}-0.72 \\
(0.064)\end{array}$ & $\begin{array}{l}-0.67 \\
(0.020)\end{array}$ \\
\hline Debt/GDP & $\cdots$ & $\begin{array}{l}-0.002 \\
(0.748)\end{array}$ & $\cdots$ \\
\hline Paper dummy & $\cdots$ & $\cdots$ & $\begin{array}{l}-1.745 \\
(0.369)\end{array}$ \\
\hline Constant & $\begin{array}{c}27.82 \\
(0.000)\end{array}$ & $\begin{array}{l}13.305 \\
(0.248)\end{array}$ & $\begin{array}{l}36.07 \\
(0.01)\end{array}$ \\
\hline $\begin{array}{l}\text { Observations } \\
\text { Log likelihood }\end{array}$ & $\begin{aligned} 140 \\
-2.25 \\
\end{aligned}$ & $\begin{array}{c}81 \\
1.31 \\
\end{array}$ & $\begin{array}{r}140 \\
-1.84 \\
\end{array}$ \\
\hline
\end{tabular}

There is also evidence that the level of development accelerated the move to the gold standard. A one standard deviation increase in real per capita output - an increase of roughly 50 percent-decreases the median expected adoption time by almost seven years. This provides some rough evidence for the notion that the gold standard was better suited for more developed countries. However, this could also be picking up the relationship between good financial systems and adoption since better financial systems are often associated with higher levels of per capita output.

Figure 2 plots some of the covariates for a few countries in the sample and the predicted time until adoption from 1870 for the level of covariates in a given year. The case of Holland most clearly illustrates how external regime changes interacted with the propensity to adopt the gold standard. There is a sharp fall in the predicted time until adoption after Germany adopted the gold standard and as gold reserves increased. Japan levels of deficits. Perhaps a "lemons" market developed at high levels of borrowing making it hard for countries with large debt burdens to obtain the good housekeeping seal. 
Figure 2: Covariates and Predicted Adoption Times, 1870 to 1913

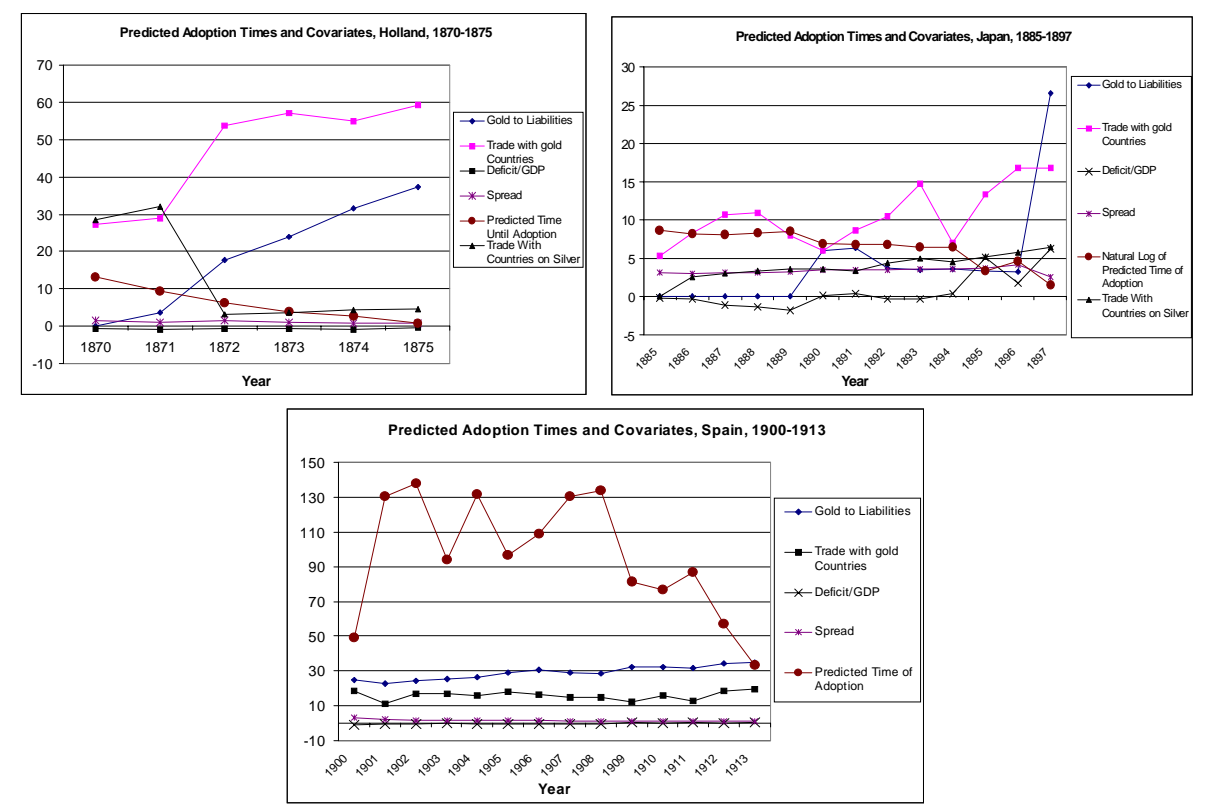

tells a similar story. Spain's data show that regimes are not predicted to change in the near future when trade links or other covariates show little change.

I also explore in greater depth the possibility that countries with weak governmental financial systems took longer to adopt. Column 2 includes a public debt to output ratio. The sample size shrinks because of data constraints, and the coefficient is small, negative and not statistically significant. Simply adding a paper regime indicator variable to the baseline regression shows that after controlling for other factors paper countries did not wait longer to adopt the gold standard. Nevertheless it may be that gold reserves, the deficit ratio and output per capita are picking up some measure of fiscal responsibility. If these variables are left out, high levels of debt are associated with delayed adoption of the gold standard.

Columns 2 and 3 of Table 4 test the possibility that the emergence of the gold standard is working through an incipient gold standard ideology. Column 2 includes the number of countries in the world on gold as a regressor. The coefficient suggests an ideological story, but it is highly statistically insignificant. I also try to avoid the problem that the 
Table 4: Other Specifications

\begin{tabular}{|c|c|c|c|}
\hline$\overline{\overline{E x p l a n a t o r y} \text { Variable }}$ & $\begin{array}{c}\text { Long } \\
\text { Specification } \\
\end{array}$ & $\begin{array}{c}\text { Ideology vs. } \\
\text { Transaction Costs } \\
\end{array}$ & $\begin{array}{c}\text { Ideology vs. } \\
\text { Transaction Costs II }\end{array}$ \\
\hline $\begin{array}{l}\text { Ratio of trade with } \\
\text { gold standard countries to GDP }\end{array}$ & $\begin{array}{l}-0.125 \\
(0.057)\end{array}$ & $\begin{array}{l}-0.097 \\
(0.026)\end{array}$ & $\cdots$ \\
\hline $\begin{array}{l}\text { Ratio of trade with countries } \\
\text { on samestandard to GDP }\end{array}$ & $\begin{array}{l}-0.012 \\
(0.920)\end{array}$ & $\begin{array}{l}-0.008 \\
(0.932)\end{array}$ & $\cdots$ \\
\hline In (realpercapita output) & $\begin{array}{l}-3.351 \\
(0.095)\end{array}$ & $\begin{array}{c}-2.72 \\
(0.045)\end{array}$ & $\begin{array}{l}-2.612 \\
(0.045)\end{array}$ \\
\hline $\begin{array}{l}\text { Ratio of gold reserves } \\
\text { to notes outstanding }\end{array}$ & $\begin{array}{l}-0.092 \\
(0.026)\end{array}$ & $\begin{array}{c}-0.08 \\
(0.003)\end{array}$ & $\begin{array}{l}-0.064 \\
(0.001)\end{array}$ \\
\hline Bond Spread & $\begin{array}{l}-1.382 \\
(0.271)\end{array}$ & $\begin{array}{l}-1.047 \\
(0.324)\end{array}$ & $\begin{array}{l}-0.502 \\
(0.439)\end{array}$ \\
\hline Ratio of deficit to output & $\begin{array}{l}-0.722 \\
(0.127)\end{array}$ & $\begin{array}{l}-0.542 \\
(0.021)\end{array}$ & $\begin{array}{l}-0.437 \\
(0.001)\end{array}$ \\
\hline A gricultural $O$ utput to GDP & $\begin{array}{l}-0.002 \\
(0.958)\end{array}$ & $\cdots$ & $\cdots$ \\
\hline $\begin{array}{l}\text { Silver Reserves } \\
\text { ( } m \text { of pounds sterling) }\end{array}$ & $\begin{array}{l}-0.083 \\
(0.228)\end{array}$ & $\cdots$ & $\cdots$ \\
\hline Exchange rate volatility & $\begin{array}{l}-0.496 \\
(0.426)\end{array}$ & $\cdots$ & $\cdots$ \\
\hline Number of Countries on Gold & $\begin{array}{l}-0.092 \\
(0.593)\end{array}$ & $\begin{array}{l}-0.044 \\
(0.735)\end{array}$ & $\begin{array}{c}0.089 \\
(0.755)\end{array}$ \\
\hline $\begin{array}{l}\text { Openness }= \\
(\text { Exports + Imports }) / G D P\end{array}$ & $\ldots$ & $\ldots$ & $\begin{array}{l}0.023 \\
(0.842)\end{array}$ \\
\hline $\begin{array}{l}\text { Openness* Number of Countries } \\
\text { on Gold }\end{array}$ & & $\cdots$ & $\begin{array}{l}-0.004 \\
(0.628)\end{array}$ \\
\hline Constant & $\begin{array}{l}40.833 \\
(0.081)\end{array}$ & $\begin{array}{l}31.844 \\
-0.038\end{array}$ & $\begin{array}{l}26.574 \\
(0.021)\end{array}$ \\
\hline $\begin{array}{l}\text { Observations } \\
\text { Log likelihood }\end{array}$ & $\begin{array}{r}140 \\
-0.88 \\
\end{array}$ & $\begin{array}{l}140 \\
-2.17 \\
\end{array}$ & $\begin{array}{l}144 \\
-3.70 \\
\end{array}$ \\
\hline
\end{tabular}

gold network effect includes information about the number of countries on gold. To do so I include a standard openness measure (ratio of the sum of imports and exports to GDP) along with the total number of countries on gold and an interaction term between the two. First the coefficients are all statistically insignificant. Nevertheless, at the mean level of openness the point estimates suggest earlier adoption the larger the size of the gold bloc. But the relation between adopting gold and openness is also consistent with a transaction costs story. For a larger number of countries on gold the openness effect is stronger..$^{35}$

In column 1 of Table 4, I present one test of the other hypotheses of Section 3.3. An extended model provides a slightly better fit while key regressors relating to the good housekeeping seal of approval become statistically insignificant. A log-likelihood test

\footnotetext{
${ }^{35}$ With no interaction term only the openness coefficient is significant. This is consistent with a transaction cost story but is not consistent with an ideology story. In the model presented, coefficients are also insignificant if I include the population weighted size of the gold bloc or the percentage of countries on gold in the world. Also since the number of countries increases with time I controlled for time dependence with a Weibull model. The results were similar.
} 
between the shorter baseline specification of column 1 Table 3 and column 1 of Table 4 cannot reject that the shorter model is an equivalent specification. Given the theoretical support and the historical evidence, there is little reason to discount the estimates and statistical significance of the covariates included in column 1 of Table 3.

Nevertheless the results in column 1 from Table 4 are telling. The silver reserves story and the desire to avoid high levels of exchange rate volatility are not evident in the data. ${ }^{36}$ Furthermore the indirect test of the conventional creditors versus debtors story also finds no support. Here, a larger primary sector accelerates adoption but the coefficient is statistically insignificant. What explains these negative results?

The statistical insignificance of the level of exchange rate volatility seems to square with the results from López-Córdova and Meissner (2000) and Flandreau and Maurel (2001). Both studies find that exchange rate volatility had no statistically significant relationship with trade in the late nineteenth century. Testimony in the US Congress suggested that the magnitude of fluctuations in the exchange rate were of little importance for importers (U.S. Commission on International Exchange (1904)). Moreover, the level of exchange rate volatility may be less relevant than the cost of hedging any volatility. My results suggest that the costs arising from nominal exchange rate volatility did not depend on its level.

Debtor interests may only be a valid explanation in certain cases or at certain points in time. In the early 1870s, before silver massively depreciated, few imagined that silver or bimetallism could be highly inflationary. In the late 1890s, new gold discoveries and the substitution of foreign assets for gold reserves (i.e., the "gold exchange standard") made the deflation associated with gold less of an issue. The price level was a live issue in the U.S.A. and other countries between the late 1870s and the early 1890s, but as Frieden (1997) shows this can be interpreted as the manifestation of export interests pushing for price supports. Frieden also remarks that voting records in the US have found there

\footnotetext{
${ }^{36}$ As an alternative measure of exchange rate volatility, I used the trade-weighted difference between volatility under the current regime and the volatility England had against other countries. A large positive difference would imply a lower trade-weighted volatility under the gold standard. This measure performs no better than the others.
} 
was little support for anti-gold Populist candidates where mortgage values were high. Flandreau (1996) points out how banking interests were strong advocates of bimetallism in the 1860s and early 1870s. The sign of this coefficient in a dynamic cross-national study is predictably ambiguous and it is likely to be statistically insignificant.

Finally, the silver argument may be logically consistent, but few countries in my sample actually had large holdings. Moreover, the variation in the data is too large to get a precise estimate of the coefficient. Nevertheless this issue certainly loomed large in the minds of Bank of France officials (Flandreau (1996)). On the other hand, it may have paid for countries with large holdings like Germany to act quickly. These factors could be influencing the results but lack of data makes generalizations about this association difficult at the cross-country level.

Despite this, the positive results from Table 3 and 4 are clear. A network externalities story combined with a sound financial system (mainly a sound fiscal position) play a significant role in explaining the timing of the adoption of the gold standard. As the world went to gold, trade with gold standard countries began to make up a larger portion of domestic output, and it came to be ever-more irresistible to adopt the gold standard. Network externalities helped define the shape of the international monetary regime of the late nineteenth century. Some evidence also shows that countries with moderate financing needs adopted earlier. A certain level of development was also necessary to adopt gold early. The following section tests the robustness of results in column 1 of Table 3.

\subsection{Sensitivity Analysis}

\section{Alternative Specifications}

In Table 3 I used the exponential model which imposes the idea that the propensity to adopt in one period is independent from any previous period. Column 1 in Table 5 uses the Weibull parameterization of the hazard rate to allow for positive or negative "duration dependence". The results are comparable, so the conclusions above are not 
swayed by the exponential parameterization. ${ }^{37}$

\section{Linear Probability Specification}

The next two columns use a linear probability model (i.e., OLS where the dependent variable is a zero in years of non-adoption and one in the year of adoption). ${ }^{38}$ The motivation for using this model is to see better if the duration model has relied on crosssectional or time-series variation in the covariates to identify the parameters. ${ }^{39}$ The results without country controls are qualitatively similar to earlier results from Table 3. It is reassuring to see that a more flexible parameterization returns similar results. To see if the results come from time-series variation, I use country fixed effects in the basic linear regression. This technique also eliminates any unobserved cross-country heterogeneity. ${ }^{40}$ Column 3 of Table 5 shows that the qualitative results are virtually identical to the exponential duration model estimates from Table $3 .{ }^{41}$ The results from this different parameterization are also mostly consistent with the baseline regression and suggest the estimation results are coming from time-series variation in the data.

\section{Omitted Variable Bias/Endogeneity}

Finally, I address the potential problem of simultaneity bias and omitted variables. López-Córdova and Meissner (2000) and Flandreau and Maurel (2001) show that bilateral trade may increase dramatically when two countries are on the gold standard. This paper argues that a country would be more likely to be move to gold the more it traded with other gold standard countries. There is a possibility that the coefficient on the ratio of trade with gold standard countries to GDP is biased due to the presence of simultaneity

\footnotetext{
${ }^{37} \mathrm{~A}$ log-likelihood ratio test shows we cannot reject the hypothesis that an exponential model is a valid specification.

${ }^{38}$ Here I am estimating the conditional probability of adoption and assuming time-independence of adoption (as in the exponential model).

${ }^{39}$ One drawback of this model, compared to the duration analysis, is the difficulty of treating the censored observations and the known inefficiency of the estimators due to heteroscedasticity. The potential bias would appear to be small given the number of observations actually censored.

${ }^{40}$ There are methods for controlling for unobserved heterogeneity in a duration model. Unreported specifications that do so provide similar results to the fixed effects regression. Staying with the linear model allows greater facility in dealing with inference and comparability in the instrumental variables estimations.

${ }^{41}$ A "between" regression of the dependent variable on within-country mean values of covariates revealed no statistical relationships between the regressors and adoption.
} 
or possibly because of omitted variables that are correlated with trade networks and monetary regime choice.

To see if these issues pose a problem I use instrumental variables techniques. To find instruments for the ratio of trade with gold standard countries to GDP, I use a gravity approach inspired by Frankel and Romer (1999). As instruments, I use the fitted values from the following first-stage regression

trade with gold countries ${ }_{i t} / \mathrm{GDP}_{i t}=\beta_{0}+\beta_{1} \ln \left(\operatorname{population}_{i t}\right)+$

$$
\beta_{2} \ln (\text { mean distance to gold countries } i t)+\beta_{3}\left(\operatorname{border}_{i t}\right)+\nu_{i t}
$$

where mean distance to gold countries is the average great circle distance from all gold standard countries to country $i$ and "border" is an indicator equal to one if country $i$ has at least one border country on the gold standard in year $t .^{42}$

The gravity approach also asserts that distance from a country (sharing a border) is inversely (directly) related to the level of trade with a country. There is no reason to believe that the predetermined geographic or demographic characteristics of countries should be correlated with possible omitted variables that drive countries to adopt the gold standard earlier or later. On the other hand, recent trade literature shows that these variables strongly influence the level of trade.

The last column of Table 5 reports results from the first-stage regression; the model fits well, has an $R$-squared of 0.42 and rejects the null hypothesis for zero slopes (F-value $=76.26)$. The correlation between the predicted values and the dependent variable is 0.65. ${ }^{43}$ Column 4 in Table 5 simply uses the fitted values from the first-stage regression in the baseline duration model. The standard errors have not been corrected for the variance in the regressor, and the technique is less efficient as would be expected. However, the magnitude of the coefficient on the ratio of trade with gold standard countries

\footnotetext{
${ }^{42}$ The distance measure is taken from Rose (2000) and is for the modern definition of boundaries. Given my sample this is unlikely to skew the results.

${ }^{43} \mathrm{~A}$ regression of the dependent variable on the predicted values gives a coefficient of one which is statistically significant at more than the 99 percent level of confidence.
} 
Table 5: Instrumental Variables Specifications

\begin{tabular}{|c|c|c|c|c|c|c|c|}
\hline \multirow[t]{2}{*}{ Explanatory Variables } & \multirow{2}{*}{$\begin{array}{l}\text { Weibull } \\
\text { Duration }\end{array}$} & \multirow[t]{2}{*}{ "Linear Probability } & \multirow{2}{*}{$\begin{array}{l}\text { Linear Probability } \\
\text { Fixed Effects }\end{array}$} & \multirow{2}{*}{$\begin{array}{l}\text { Exponential Duration } \\
\text { IV }\end{array}$} & \multirow{2}{*}{$\begin{array}{c}\text { Linear Probability } \\
\text { IV }\end{array}$} & \multicolumn{2}{|c|}{ 1st Stage Regression } \\
\hline & & & & & & Instruments & \\
\hline $\begin{array}{l}\text { Ratio of trade with } \\
\text { gold standard countries to GDP }\end{array}$ & $\begin{array}{l}-0.067 \\
(0.000)\end{array}$ & $\begin{array}{c}0.007 \\
(0.003)\end{array}$ & $\begin{array}{l}0.008 \\
(0.004)\end{array}$ & $\begin{array}{l}-0.034 \\
(0.714)\end{array}$ & $\begin{array}{l}0.008 \\
(0.009)\end{array}$ & In (population) & $\begin{array}{c}-5.84 \\
(0.386)\end{array}$ \\
\hline $\begin{array}{l}\text { Ratio of trade with countries } \\
\text { on same standard to GDP }\end{array}$ & $\begin{array}{l}-0.011 \\
(0.737)\end{array}$ & $\begin{array}{l}-0.003 \\
(0.006)\end{array}$ & $\begin{array}{l}-0.007 \\
(0.005)\end{array}$ & $\begin{array}{l}-0.001 \\
(0.993)\end{array}$ & $\begin{array}{l}-0.004 \\
(0.007)\end{array}$ & $\begin{array}{l}\text { Average distance } \\
\text { to gold standard } \\
\text { countries }\end{array}$ & $\begin{array}{l}-0.571 \\
(0.997)\end{array}$ \\
\hline In (real per capita output) & $\begin{array}{l}-2.001 \\
(0.000)\end{array}$ & $\begin{array}{c}0.098 \\
(0.037)\end{array}$ & $\begin{array}{l}-0.437 \\
(0.202) \\
(0.045)\end{array}$ & $\begin{array}{l}-2.319 \\
(0.039)\end{array}$ & $\begin{array}{l}0.099 \\
(0.042)\end{array}$ & $\begin{array}{l}\text { Border dummy } \\
\text { (one if at least one }\end{array}$ & $\begin{array}{c}5.79 \\
(1.31)\end{array}$ \\
\hline $\begin{array}{l}\text { Ratio of gold reserves } \\
\text { to notes outstanding }\end{array}$ & $\begin{array}{l}-0.052 \\
(0.000)\end{array}$ & $\begin{array}{c}0.002 \\
(0.002)\end{array}$ & $\begin{array}{l}0.005 \\
(0.002) \\
(0.001)\end{array}$ & $\begin{array}{l}-0.047 \\
(0.007)\end{array}$ & $\begin{array}{c}0.002 \\
(0.001)\end{array}$ & $\begin{array}{l}\text { gold standard } \\
\text { country on border) }\end{array}$ & \\
\hline Bond Spread & $\begin{array}{l}-0.911 \\
(0.000)\end{array}$ & $\begin{array}{c}0.034 \\
(0.018)\end{array}$ & $\begin{array}{l}-0.008 \\
(0.031) \\
(0.439)\end{array}$ & $\begin{array}{l}-0.0002 \\
(1.000)\end{array}$ & $\begin{array}{c}0.04 \\
(0.049)\end{array}$ & Constant & $\begin{array}{l}33.34 \\
(8.47)\end{array}$ \\
\hline Ratio of deficit to output & $\begin{array}{l}-0.378 \\
(0.000)\end{array}$ & $\begin{array}{c}0.028 \\
(0.015)\end{array}$ & $\begin{array}{l}0.029 \\
(0.009) \\
(0.001)\end{array}$ & $\begin{array}{l}-0.334 \\
(0.073)\end{array}$ & $\begin{array}{c}0.028 \\
(0.015)\end{array}$ & & \\
\hline Constant & $\begin{array}{l}23.62 \\
(0.000)\end{array}$ & $\begin{array}{l}-0.904 \\
(0.306)\end{array}$ & $\begin{array}{l}2.934 \\
(1.454)\end{array}$ & $\begin{array}{l}23.147 \\
(0.010)\end{array}$ & $\begin{array}{l}-0.942 \\
(0.495)\end{array}$ & & \\
\hline Observations & 140 & 140 & 140 & 141 & 140 & & 351 \\
\hline R-squared & & 0.15 & & & 0.15 & & 0.42 \\
\hline Log Likelihood & -1.35 & & & -4.94 & & & \\
\hline Root MSE & & 0.20 & & & 0.20 & & 8.87 \\
\hline
\end{tabular}

Notes: The p-values for the null hypothesis that the coefficient is zero based on robust standard errors are in parentheses in columns 1 and 4. Standard errors are reported in columns 2,3, 5 and 7 . In column 1 and 4 , the dependent variable can be interpreted as the natural logarithm of the time of adoption (see text). The dependent variable in columns 2,3 and 5 is one if a country adopted gold convertibility in a given year and zero if it did not adopt gold. The dependent variable in the final column is trade with gold standard countries divided by GDP. In column 1 and 4 a one unit change in the explanatory variable is associated with a (exp(beta)-1)*100 percent change in the time until adoption of the gold standard. The coefficients in columns 2,3 and 5 report the change in the probability of adoption given a one unit change in the regressor.

is qualitatively similar to the baseline specification. The next column uses the linear probability model on the pooled data. Because instrumental variables estimates are less efficient, the statistical significance of the network variable is diminished. However, the magnitude and direction of the network effect with gold standard countries is still positive and similar to those of Column 2. A Hausman test for exogeneity cannot reject the null hypothesis that the trade network variable is exogenous. There is no evidence of an endogeneity bias affecting the qualitative results.

Finally, unreported regressions tested the sensitivity of the baseline exponential results to possible outliers and disputes in the date of adoption of gold convertibility. I dropped each country, one at a time, from the econometric sample, and ran the duration model from column 1 Table 3. The qualitative conclusions were not altered. Similarly, changing the dates of adoption to coincide with other authors' dating of the adoption of the gold standard makes no significant difference to the results. ${ }^{44}$

\footnotetext{
${ }^{44}$ I changed the date of adoption for Norway to 1875 from 1873; I allowed Austria-Hungary to adopt
} 


\section{Conclusions}

The diffusion of the gold standard after 1870 is about the switch from an early regime equilibrium to a new equilibrium. The path followed reflected changing trade patterns, financial needs and domestic constraints. Ultimately, institutions crossed borders handin-hand with globalization in factor markets. Institutional homogenization can largely be rationalized on the basis of readily observable characteristics. Nevertheless the fact that there came to be an international gold standard and not an international silver standard owes itself largely to Britain's early steadfast adherence to gold and its commercial and financial significance. The timing of the commencement of the global diffusion appears to have depended on a small number of historical events. However, once the process was set in motion, a more deterministic path based on economic fundamentals was followed.

In the end, most countries found it more valuable to join the gold standard when trade with other gold standard countries made up a large proportion of national income and when they traded relatively little with countries on other commodity standards. Older regimes became less beneficial as important nations switched to gold. The European silver bloc imploded shortly after 1872 with the German and Scandinavian switch to gold. Bimetallism in France and neighboring countries could not survive the impact of the global appetite for gold. The gold standard fanned out to more peripheral parts of the world as commercial and financial globalization marched inexorably onwards.

Besides trade, better access to international capital markets may also have motivated countries to adopt the gold standard early on. The gold standard may have acted as a "good housekeeping seal of approval". More developed countries appear to have adopted gold sooner. Along these lines, evidence suggests that countries with unsustainable fiscal policies or perhaps un-regulated banking systems delayed adoption of the gold standard.

On the other hand, the cross-country analysis also finds little evidence that opposition by debtor interests delayed adoption of the gold standard. Neither did national interests gold in 1902 as in Flandreau, Le-Cacheux, and Zumer (1998); finally, as Italy had a relatively stable currency between 1893 and 1913 I dropped it from the sample in that period, in effect treating it as if it were actually on gold. 
seem preoccupied by the level of exchange rate volatility. The gold standard appears to be more about transaction costs than risk-aversion. Finally there is little evidence that countries with large silver reserves made a late switch to gold.

At this point it is worth noting the existence of a virtuous circle where integration helped determine regime choice and regime choices spurred further integration. The rise of coordination on the gold standard may have depended on already evident commercial trends, but if transaction costs mattered, it also appears to have catalyzed an emergent process of Smithian growth. In turn, the emergence of the classical gold standard after 1870 may have substantially contributed to rapidly advancing living standards in the decades preceding 1913. 


\section{References}

ACEÑA, P. M. (2000): "The Spanish Monetary Experience, 1848-1914," in Monetary Standards in the Periphery, ed. by P. M. Aceña, and J. Reis. St. Martin's Press, New York.

Alesina, A., And R. J. Barro (2000): "Currency Unions," Working Paper 7927, National Bureau of Economic Research.

Allison, P. D. (1995): Survival Analysis Using the SAS System. SAS Publishing, Cary, $\mathrm{NC}$.

BARBIERI, K. (1996): "Economic Interdependence and Militarized Interstate Conflict, 1870-1985," Ph.D. thesis, Binghampton University.

BARKAi, H. (1973): "The Macro-Economics of Tsarist Russia in the Industrialization Era: Monetary Developments, the Balance of Payments and the Gold Standard," Journal of Economic History, 33, 339-371.

Bordo, M., and M. Flandreau (2001): "Core, Periphery, Exchange Rate Regimes and Globalization," Paper prepared for the NBER Globalization in Historical Perspective Conference.

Bordo, M., And F. E. Kydland (1997): "The Gold Standard as a Rule," in The Gold Standard in Theory and History, ed. by B. Eichengreen, and M. Flandreau. Routledge, New York.

Bordo, M., and H. Rockoff (1996): "The Gold Standard as a Good Housekeeping Seal of Approval," Journal of Economic History, 56(2), 389-428.

Bordo, M., and A. Schwartz (1995): "The Operation of the Specie StandardEvidence for Core and Peripheral Countries," in Currency Convertibility: The Gold Standard and Beyond, ed. by J. B. de Macedo, B. Eichengreen, and J. Reis. Routledge, London.

Bordo, M. D., and C. A. VÉGH (1998): "What if Alexander Hamilton had Been Argintinean? A Comparison of the Early Monetary Experiences of Argentina and the United States," Working Paper 6862, National Bureau of Economic Research.

Calogeras, J. P. (1960): A Politica Monetaria Do Brasil. Companhia Editora Nacional, Sao Paulo.

Carbo, L. A. (1954): Historia Monetaria y Cambiaria del Ecuador Desde Epoca Colonial. Quito, Ecuador.

Commission on International Exchange (1904): Report on the Introduction of the Gold-Exchange Standard into China, the Philippine Islands, Panama, and other silver-using Countries and on the Stability of Exchange. Government Printing Office, Washington, D.C.

CRISP, O. (1953): "Russian financial policy and the Gold Standard at the end of the nineteenth century," Economic History Review, 6, 156-172.

Cuccorese, H. J. (1972): Historia Económica Financiera Argentina 1862-1930. El Atenéo, Buenos Aires. 
DE CEcco, M. (1974): Money and Empire: The International Gold Standard, 18901914. Basil Blackwell, Oxford.

Ding, C. H. (1978): A History of Straits Settlements Foreign Trade. National Museum of Singapore, Singapore.

Dritsas, M. (1999): "Monetary Modernisation in Greece: Bimetallism or the Gold Standard," Journal of European Economic History, 28(1), 9-48.

Eichengreen, B. (1996): Globalizing Capital: A History of the International Monetary System. Princeton University Press, Princeton, New Jersey.

(1999): "The Baring Crisis in a Mexican Mirror," International Political Science Review, 20(3), 249-270.

Eichengreen, B., and M. Flandreau (1998): "The Geography of the Gold Standard," in Currency Convertibility: The Gold Standard and Beyond, ed. by J. B. de Macedo, B. Eichengreen, and J. Reis. Routledge, London.

Einaudi, L. (2000): "From the Franc to the 'Europe': The attempted transformation of the Latin Monetary Union into a European Monetary Union, 1865-1873," Economic History Review, 53(2).

(2001): Money and Politics: European Monetary Unification and the International Gold Standard, 1865-1873. Oxford University Press, Oxford.

Flandreau, M. (1996): "The French Crime of 1873: An Essay in the Emergence of the International Gold Standard, 1870-1880," Journal of Economic History, 56(4), $862-897$.

(2000): "The Economics and Politics of Monetary Unions: A Reassessment of the Latin Monetary Union, 1865-71," Financial History Review, 7, 25-43.

Flandreau, M., and J. Komlos (2002): "Core of Periphery? The Credibility of the Austro-Hungarian Currency, 1867-1913," mimeo. University of Munich.

Flandreau, M., J. Le-Cacheux, and F. Zumer (1998): "Stability Without a Pact? Lessons from the European Gold Standard, 1880-1914," Economic Policy, pp. 115-149.

Flandreau, M., and M. Maurel (2001): "Monetary Union, Trade Integration and Business Fluctuations in 19th Century Europe: Just Do It," Working Paper 3087, CEPR.

Frankel, J. A., And D. Romer (1999): "Does Trade Cause Growth?," American Economic Review, 89(3), 379-399.

Fratianni, M., and F. Spinelli (1997): A Monetary History of Italy. Cambridge University Press, New York.

Frieden, J. A. (1997): "Monetary Populism in Nineteenth-Century America: An Open Economy Interpretation," The Journal of Economic History, 57(2), 367-395.

Fritsch, W., And G. H. Franco (2000): "Brazilian Experience with the Gold Standard," in Monetary Standards in the Periphery, ed. by P. M. Aceña, and J. Reis. St. Martin's Press, New York. 
Gallarotti, G. M. (1995): The Anatomy of an International Monetary Regime. Oxford University Press, New York.

Henriksen, I., and N. Kaergard (1995): "The Scandinavian Currency Union 18751914," in International Monetary Systems in Historical Perspective, ed. by J. Reis. St. Martin's Press, New York.

House of Commons (1876): Report from the Select Committee on the Depreciation of Silver together with the Proceedings of the Committee, Minutes of Evidence and Appendix.

Kemmerer, E. (1916): Modern Currency Reforms. The Macmillan Co., New York.

Lazaretou, S. (1995): "Government Spending, Monetary Policies and Exchange Rate Regime Switches: The Drachma in the Gold Standard Period," Explorations in Economic History, 32, 28-50.

Llona-Rodríguez, A. (2000): "Chile During the Gold Standard: A Successful Paper Money Experience," in Monetary Standards in the Periphery, ed. by P. M. Aceña, and J. Reis. St. Martin's Press, New York.

López-Córdova, J. E., And C. Meissner (2000): "Exchange Rate Regimes and International Trade: Evidence from the Classical Gold Standard Era," Discussion Paper C00-118, Center for International and Development Economics Research (CIDER) University of California at Berkeley.

Masayoshi, C. M. (1899): Report on the Adoption of the Gold Standard in Japan. Government Printing Press, Tokyo.

Meyer, J. (1878): "The World's Money: Theory of the Coin, Coinage and the Monetary System of the World," in Pahmplets on Finance, vol. 5. Government Printing Office, London.

Mitchell, B. R. (1992): International Historical Statistics. Europe 1750-1988. Stockton Press, New York.

Moreno, R. (2000): "Does Pegging Increase International Trade?," Federal Reserve Bank of San Francisco, (2000).

Muhleman, M. L. (1895): Monetary Systems of the World A Study of Present Currency Systems and Statistical Information Relative to the Volume of the World's Money with Complete Abstracts of Various Plans Proposed for the Solution of the Currency Problem. Charles Nicoll, New York.

Nash, R. L. (Various issues): Fenn's Compendium of the English and Foreign Funds, Debt, and Revenue of All Nations, Together with Statistics Relating to National Resources and Liabilities, Imports, Exports, Population, Area, Railway Guarantees, Municipal Finance and Indebtedness, Banks of All Nations and all Descriptions of Government, Provincial and Corporate Securities held and dealt in by Investors at Home and Abroad.

Nitsch, V. (2002): "Honey, I Shrunk the Currency Union Effect on Trade," The World Economy, 25(4), 457-474. 
Obstfeld, M. (1997): "Europe's Gamble," Brookings Papers on Economic Activity, (2), 241-317.

Obstfeld, M., and K. Rogoff (2000): "The Six Major Puzzles in International Macroeconomics: Is There a Common Cause?," in NBER Macroeconomics Annual, ed. by B. S. Bernanke, and K. Rogoff. MIT Press, Cambridge.

Persson, T. (2001): "Currency Unions and Trade: How Large is the Treatment Effect?," Economic Policy, 16(33), 433-462.

Quintero-Ramos, A. M. (1965): A History of Money and Banking in Argentina. University of Puerto Rico, Rio Piedras P.R.

Redish, A. (1990): "The Evolution of the Gold Standard in England," Journal of Economic History, 50, 789-806.

(2000): Bimetallism: An Economic and Historical Analysis. Cambridge University Press, New York.

ReIS, J. (1998): "First to Join the Gold Standard, 1854," in Currency Convertibility: The Gold Standard and Beyond, ed. by J. B. de Macedo, B. Eichengreen, and J. Reis. Routledge, London.

(2000): "The Gold Standard in Portugal, 1854-1891," in Monetary Standards in the Periphery, ed. by P. M. Aceña, and J. Reis. St. Martin's Press, New York.

Rose, A. K. (2000): "One Money, One Market: Estimating the Effect of Common Currencies on Trade," Economic Policy, 30, 7-45.

Rousseau, P. L., and R. Sylla (2001): "Financial Systems, Economic Growth and Globalization," Working Paper 8323, National Bureau of Economic Research.

Russell, H. B. (1898): International Monetary Conferences. Harper and Brothers, New York.

Schneider, J., O. Schwarzer, and F. Zellfelder (1991): Wahrüngen der Welt. Verlag, Stuttgart.

SEyd, E. (1868): Bullion and Foreign Exchange. Effingham Wilson, London.

Subercaseaux, G. (1922): Monetary and Banking Policy of Chile. Clarendon Press, Oxford.

Sussman, N., and Y. Yafeh (2000): "Institutions, Reforms and Country Risk: Lessons from Japanese Government Debt in the Meiji Era," Journal of Economic History, $60(2), 442-467$.

TAliA, K. (2001): "Monetary Integration and Disintegration: Studies in the Scandinavian Currency Union, 1873-1924," mimeo. Stockholm School of Economics.

Tattara, G. (2000): "Was Italy Ever on Gold?," in Monetary Standards in the Periphery, ed. by P. M. Aceña, and J. Reis. St. Martin's Press, New York.

Tenreyro, S. (2002): "On the Causes and Consequences of Currency Unions," mimeo. Harvard University. 
Torres-Garcia, G. (1945): Historia de la Moneda en Colombia. Banco de la Republica, Bogota.

Unger, I. (1964): The Greenback Era: A Social and Political History of American Finance, 1865-1879. Princeton University Press, Princeton, NJ.

United States Monetary Commission (1879): Report of the Silver Commission, vol. II. Government Printing Office, Washington, D.C.

U.S. Commission on International Exchange (1904): Gold Standard in International Trade: Report on the Introduction of the Gold-Exchange Standard into China, the Philippine Islands, Panama and Other Silver-Using Countries. Government Printing Office, Washington, D.C.

Williams, J. H. (1920): Argentine International Trade Under Inconvertible Paper Money 1880-1900. Harvard University Press, Cambridge.

Willis, H. P. (1899): "The Austrian Currency Reform," Sound Currency, 6(8).

Wyplosz, C. (1997): "EMU: Why and How it Might Happen," Journal of Economic Perspectives, 11(4), 3-22.

Yeager, L. (1969): "Fluctuating Exchange Rates in the Nineteenth Century: The Experiences of Austria and Russia," in Monetary Problems of the International Economy, ed. by R. Mundell, and A. Swoboda. University of Chicago Press, Chicago.

Young, J. P. (1925): Central American Currency and Finance. Princeton University Press, Princeton. 


\section{Appendix A}

\section{Data Notes}

Real GDP: Figures are from Maddison (1995). They are in real, 1990 PPP U.S.
dollars.
Volatility: I use monthly exchange rate data from the Global Financial Database and Schneider, Schwarzer, and Zellfelder (1991). Some series are for "sight" transactions on foreign exchange while others are for "three-month" or "six month" exchange rates. I operate under the assumption these series never diverge significantly. We observe that in some cases, when all series are available, this is in fact the case. Countries for which we use data from Schneider, Schwarzer, and Zellfelder (1991) are France, Netherlands, Germany, Italy, Switzerland, the United States, Norway, Sweden, Finland (before 1900), Portugal, Austria, and Belgium. To construct the volatility measure, I then take the standard deviation of $\ln \left(e_{i j t}\right)-\ln \left(e_{i j t-1}\right)$ multiplied by 100 . Where $e_{i j t}$ is the bilateral exchange rate between country $i$ and $j$ in month $t$. I use cross rates when necessary.

Distance and Borders: Distance is taken from Rose (2000). The data were downloaded from http://haas.berkeley.edu/ arose. He in turn lifted the data from the CIA's website. The data on borders comes from López-Córdova and Meissner (2000).

Regime Dating: Many sources were used to establish the first year of gold convertibility of a currency. Sources include Llona-Rodríguez (2000), Bordo and Schwartz (1995), Carbo (1954), Calogeras (1960), de Cecco (1974), Eichengreen and Flandreau (1998), Flandreau, Le-Cacheux, and Zumer (1998), Fratianni and Spinelli (1997), Kemmerer (1916), Lazaretou (1995), Aceña (2000), Masayoshi (1899), Muhleman (1895), QuinteroRamos (1965), House of Commons (1876), Torres-Garcia (1945), Williams (1920), Yeager (1969) and Young (1925).

Trade Data: I have two main sources for trade data. Mitchell (1992) provided most of the data. Most often data was transformed from national currency units into pounds sterling. I complemented this data with series from Barbieri (1996) when necessary. I also used a pure series from Barbieri supplementing these series with Mitchell's data in the case of missing values. Barbieri's data was transformed from current U.S. dollars into pounds sterling at the annual average exchange rate.

The data covers trade from most of the important trading partners though there is no universal cut-off value for being included in Mitchell's series. Barbieri's data are more comprehensive in general, but only independent countries are included in the data.

Gold, Specie and Notes in Circulation: This series includes all notes outstanding in the nation of question. Usually this meant using the notes in circulation of the central bank and possibly the government if these notes were convertible. For countries without central banks the notes in circulation are at all banks of issue. Only gold reserves and silver reserves held in banks were used for calculating the amount of specie in a country. See the particular country notes for the sources used.

Government deficits: I use the ratio of the difference between expenditure and revenue to nominal output or the average of current and the previous two years' deficits in some specifications. Data come from Mitchell (1992).

Government Debt: Data comes from worksheets made available by Michael D. Bordo and from various issues of Nash's Fenn's Compendium of the English and Foreign Funds

Bond Spreads: Data comes from Bordo and Rockoff (1996). 
Table 6: Countries and Variables Available in the Dataset

\begin{tabular}{|c|c|c|c|c|c|c|c|c|c|c|c|c|}
\hline Country & 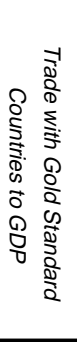 & 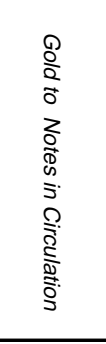 & 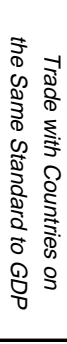 & 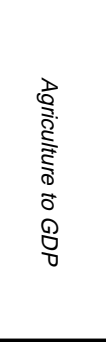 & 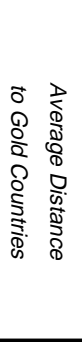 & 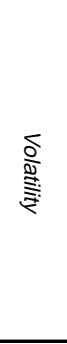 & 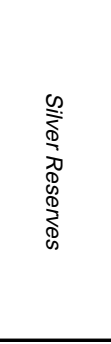 & 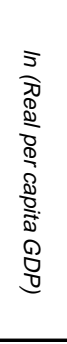 & 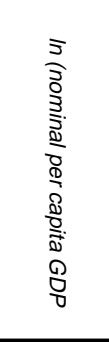 & 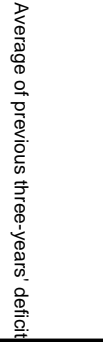 & $\begin{array}{l}\text { D } \\
\stackrel{0}{0} \\
\stackrel{0}{0} \\
0 \\
0 \\
0 \\
0 \\
\vec{D} \\
\overrightarrow{0}\end{array}$ & $\begin{array}{l}\infty \\
\frac{\infty}{0} \\
\mathbb{\infty} \\
\stackrel{2}{2}\end{array}$ \\
\hline France & $\mathrm{x}$ & $x$ & $x$ & $\mathrm{x}$ & $\mathrm{x}$ & $x$ & $x$ & $x$ & $\mathrm{x}$ & $\mathrm{x}$ & & \\
\hline US & $x$ & $x$ & $x$ & $x$ & $x$ & $x$ & $x$ & $x$ & $x$ & $x$ & $\mathrm{x}$ & $x$ \\
\hline Belgium & $x$ & $x$ & $x$ & $x$ & $x$ & $x$ & $x$ & $x$ & $x$ & $x$ & $1871,73,76-78$ & $x$ \\
\hline Switzerland & & & $x$ & $x$ & $\mathrm{x}$ & $x$ & & 1870 & $\mathrm{x}$ & $x$ & 1876 & $x$ \\
\hline Italy & $x$ & $x$ & $x$ & $x$ & $x$ & $x$ & $x$ & $x$ & $x$ & $x$ & $x$ & $x$ \\
\hline Germany & $\mathrm{x}$ & & $\mathrm{x}$ & $\mathrm{x}$ & $\mathrm{x}$ & $\mathrm{x}$ & & $\mathrm{x}$ & $\mathrm{x}$ & 1872 & & $\mathrm{x}$ \\
\hline Holland & $x$ & $\mathrm{x}$ & $x$ & $x$ & $x$ & $x$ & $\mathrm{x}$ & $x$ & $x$ & $x$ & 1872 & $x$ \\
\hline Denmark & $x$ & $x$ & $x$ & $x$ & $x$ & $x$ & $x$ & $x$ & $x$ & $x$ & 1870,72 & $x$ \\
\hline Norway & $x$ & $x$ & $x$ & $x$ & $x$ & & $x$ & $x$ & $x$ & $x$ & $1871-$ & \\
\hline Sweden & $x$ & $x$ & $x$ & $x$ & $x$ & $x$ & $x$ & $x$ & $x$ & & & $x$ \\
\hline Finland & $x$ & $x$ & $x$ & $x$ & $x$ & & & $x$ & $x$ & & & \\
\hline Austria & $x$ & $x$ & $\mathrm{x}$ & x & $\mathrm{x}$ & $x$ & $\mathrm{x}$ & $x$ & x & $\mathrm{x}$ & $1872,74,76,81,8284-94$ & $1874-1913$ \\
\hline Russia & $x$ & $x$ & $x$ & $1885-1897$ & $x$ & $x$ & $x$ & & $1885-1897$ & $x$ & $1875,76,80,87,9195,96$ & \\
\hline Spain & $x$ & $x$ & $x$ & x & $x$ & $x$ & $x$ & 1901- & $\mathrm{x}$ & $x$ & $1881,91,97$ & $x$ \\
\hline Greece & $x$ & & $x$ & $x$ & $\mathrm{x}$ & $1902-$ & & & $x$ & $x$ & $1876,81,9198$ & x \\
\hline Japan & $x$ & $x$ & $x$ & $x$ & $x$ & $x$ & $\mathrm{x}$ & $1886-$ & $1875-$ & $1885-$ & $\mathrm{x}$ & $1871-1897$ \\
\hline Brazil & $x$ & & $x$ & $x$ & $x$ & $x$ & & & $x$ & $x$ & $x$ & $\mathrm{x}$ \\
\hline Chile & $1880-$ & 1893-1895 & $x$ & & $x$ & $1879-$ & & 1900 & 1880-1894 & $1880-1894$ & $1880,87,89$ & $x$ \\
\hline Argentina & 1886- & 1886- & $x$ & & $x$ & $1886-$ & $1890-1891$ & $1900-$ & 1886- & & $1886,88-90,92,97$ & $x$ \\
\hline
\end{tabular}

